\title{
Egr-1 contributes to IL-1-mediated down- regulation of peroxisome proliferator-activated receptor $\gamma$ expression in human osteoarthritic chondrocytes
}

Sarah-Salwa Nebbaki ${ }^{1}$, Fatima Ezzahra El Mansouri ${ }^{1}$, Hassan Afif ${ }^{1}$, Mohit Kapoor ${ }^{1}$, Mohamed Benderdour ${ }^{2}$, Nicolas Duval ${ }^{3}$, Jean-Pierre Pelletier ${ }^{1}$, Johanne Martel-Pelletier ${ }^{1}$ and Hassan Fahmi ${ }^{*}$

\begin{abstract}
Introduction: Peroxisome proliferator-activated receptor (PPAR)y has been shown to exhibit anti-inflammatory and anti-catabolic properties and to be protective in animal models of osteoarthritis (OA). We have previously shown that interleukin-1 $\beta$ (IL-1) down-regulates PPAR underlying this effect have not been well characterized. The PPARy promoter harbors an overlapping Egr-1/ specificity protein 1 (Sp1) binding site. In this study, our objective was to define the roles of Egr-1 and Sp1 in IL-1mediated down-regulation of PPAR $\gamma$ expression.
\end{abstract}

Methods: Chondrocytes were stimulated with IL-1 and the expression levels of Egr-1 and Sp1 mRNAs and proteins were evaluated using real-time reverse transcriptase-polymerase chain reaction (RT-PCR) and Western blotting, respectively. The role of de novo protein synthesis was evaluated using the protein synthesis inhibitor cycloheximide (CHX). The recruitment of Sp1 and Egr-1 to the PPAR $\gamma$ promoter was evaluated using chromatin immunoprecipitation (ChIP) assays. The PPAR $\gamma$ promoter activity was analyzed in transient transfection experiments. The roles of Egr-1 and Sp1 were further evaluated using small interfering RNA (siRNA) approaches. The level of Egr1 in cartilage was determined using immunohistochemistry.

Results: Down-regulation of PPARy expression by IL-1 requires de novo protein synthesis and was concomitant with the induction of the transcription factor Egr-1. Treatment with IL-1 induced Egr-1 recruitment and reduced Sp1 occupancy at the PPAR $\gamma$ promoter. Overexpression of Egr-1 potentiated, whereas overexpression of Sp1 alleviated, the suppressive effect of IL-1 on the PPAR $\gamma$ promoter, suggesting that Egr-1 may mediate the suppressive effect of IL-1. Consistently, Egr-1 silencing prevented IL-1-mediated down-regulation of PPAR $\gamma$ expression. We also showed that the level of Egr-1 expression was elevated in OA cartilage compared to normal cartilage.

Conclusions: Our results indicate that induction and recruitment of Egr-1 contributed to the suppressive effect of IL-1 on PPARy expression. They also suggest that modulation of Egr-1 levels in the joint may have therapeutic potential in OA.

\footnotetext{
* Correspondence: h.fahmi@umontreal.ca

'Osteoarthritis Research Unit, Research Centre of the University of Montreal Hospital Center (CR-CHUM), Notre-Dame Hospital, 1560 Sherbrooke Street East, J.A. DeSève Pavillion, Y-2628, and Department of Medicine, University of Montreal, Montreal, QC H2L 4M1, Canada

Full list of author information is available at the end of the article
} 


\section{Introduction}

Osteoarthritis (OA) is the most common joint disease and is a leading cause of disability in developed countries and throughout the world. Clinical manifestations of OA may include pain, stiffness, and reduced joint motion. Pathologically, OA is characterized by progressive degeneration of articular cartilage, synovial inflammation, and subchondral bone remodeling. It is also characterized by increased levels of inflammatory mediators, among which interleukin 1 (IL-1) is considered a key player in the initiation and progression of the disease [1].

The mechanisms through which IL-1 exerts its effects include increased expression of inflammatory genes such as inducible nitric oxide synthase ( $i N O S$ ), cyclooxygenase $2(C O X-2)$, microsomal prostaglandin $E$ synthase 1 (mPGES-1), and the release of nitric oxide (NO) and prostaglandin $\mathrm{E}_{2}\left(\mathrm{PGE}_{2}\right)$ [1]. IL-1 also promotes cartilage degradation by suppressing the synthesis of the major components of extracellular matrix proteoglycan and collagen and by enhancing the production of matrix metalloproteinases (MMPs) and aggrecanases [1].

Peroxisome proliferator-activated receptors (PPARs) are a family of transcription factors belonging to the nuclear hormone receptor superfamily, which includes receptors for steroids, thyroid hormone, vitamin $\mathrm{D}$, and retinoic acid. Three PPAR isoforms have been identified: PPAR $\alpha$, $\operatorname{PPAR} \beta / \delta$, and PPAR $\gamma$ [2]. PPAR $\alpha$, present primarily in the liver, heart, and muscle, plays a central role in the regulation of fatty acid metabolism [3]. PPAR $\beta / \delta$ is ubiquitously expressed and has been suggested to participate in various physiological processes such as lipid homeostasis, epidermal maturation, tumorogenesis, wound healing, and brain development [4]. PPAR $\gamma$, the most thoroughly studied member of the PPAR family, exists as two forms as a result of differential splicing: PPAR $\gamma 1$ and PPAR $\gamma 2$. PPAR $\gamma 1$ is expressed in several tissues and cell types, whereas PPAR $\gamma 2$ is found mainly in adipose tissues. PPAR $\gamma$ plays important modulatory roles in lipid and glucose metabolism, cellular differentiation, vascular function, and immunoregulation and has been implicated in various conditions, including inflammation, atherosclerosis, and cancer [5-7].

There is increasing evidence that PPAR $\gamma$ also plays an important role in the pathophysiology of OA and other arthritic articular diseases [8]. Activation of PPAR $\gamma$ inhibits IL-1-induced $\mathrm{NO}$ and $\mathrm{PGE}_{2}$ production as well as iNOS and COX-2 expression in human and rat chondrocytes [9-12]. PPAR $\gamma$ activation was also shown to suppress the induction of mPGES-1, which catalyzes the terminal step in $\mathrm{PGE}_{2}$ synthesis $[13,14]$. In addition to having effects on inflammatory responses, PPAR $\gamma$ activation modulates several events involved in cartilage destruction. For instance, PPAR $\gamma$ activation was demonstrated to inhibit IL-1induced MMP-1, MMP-3, MMP-9, and MMP-13 expression $[9,15,16]$ as well as IL-1-mediated proteoglycan degradation [11]. Moreover, PPAR $\gamma$ activation was reported to prevent IL-1-mediated degradation of type II collagen in human OA cartilage explants [16]. Additional in vitro studies demonstrated that PPAR $\gamma$ activation suppressed several inflammatory and catabolic responses in synovial fibroblasts, including the production of tumor necrosis factor-alpha (TNF- $\alpha$ ), IL-1, IL-6, IL-8, MMP-1, and MMP-3 [17-19] and the expression of iNOS, cytosolic phospholipase A2 (cPLA2), COX-2, and mPGES-1 [20-22]. Finally, the protective effects of PPAR $\gamma$ in OA have been proven in vivo in animal models of the disease. In this context, we have demonstrated that PPAR $\gamma$ activators reduced the size, depth, and histological severity of cartilage lesions in two models of OA: the partial medial meniscectomy in guinea pigs [23] and anterior cruciate ligament transection in dogs [24].

We previously showed that IL-1 suppresses PPAR $\gamma$ expression in human OA chondrocytes [25]; however, the underlying signaling mechanisms remained undefined. The PPAR $\gamma$ proximal promoter contains an overlapping binding site for the transcription factors Egr-1 (early growth response gene 1 ) and $\mathrm{Sp} 1$ (specificity protein 1 ). In the present study, we demonstrated that Egr-1 contributes to the suppressive effect of IL- 1 on PPAR $\gamma$ expression, likely through displacement of prebound Sp1.

\section{Materials and methods}

\section{Reagents and antibodies}

Human recombinant IL-1 was obtained from Genzyme (Cambridge, MA, USA). Aprotinin, leupeptin, pepstatin, phenylmethylsulphonyl fluoride (PMSF), cycloheximide (CHX), and sodium orthovanadate $\left(\mathrm{Na}_{3} \mathrm{VO}_{4}\right)$ were from Sigma-Aldrich Canada (Oakville, ON, Canada). Dulbecco's modified Eagle's medium (DMEM), penicillin and streptomycin, fetal calf serum (FCS), and Trizol reagents were supplied by Invitrogen (Burlington, ON, Canada). Antibodies against Egr-1, Sp1, and $\beta$-actin were purchased from Santa Cruz Biotechnology, Inc. (Santa Cruz, CA, USA). The antibody against PPAR $\gamma$ was from Cayman Chemical Company (Ann Arbor, MI, USA). Polyclonal goat anti-rabbit immunoglobulin G (IgG) with horseradish peroxidase (HRP) was from Pierce (Rockford, IL, USA).

\section{Specimen selection and chondrocyte culture}

Human normal cartilage (from femoral condyles) was obtained at necropsy, within 12 hours of death, from donors with no history of arthritic diseases $(n=12$, mean \pm standard deviation (SD) age: $61 \pm 14$ years). To ensure that only normal tissue was used, cartilage specimens were thoroughly examined both macroscopically and microscopically. Only those with neither alteration were further processed. Human OA cartilage was obtained from patients undergoing total knee replacement $(n=31$, 
mean \pm SD age: $66 \pm 15$ years). In all patients, OA was diagnosed on the basis of criteria developed by the American College of Rheumatology Diagnostic Subcommittee for OA [26]. At the time of surgery, the patients had symptomatic disease requiring medical treatment in the form of non-steroidal anti-inflammatory drugs or selective COX-2 inhibitors. Patients who had received intraarticular injections of steroids were excluded. The Clinical Research Ethics Committee of Notre-Dame Hospital approved the study protocol and the use of human articular tissues. Informed consent was obtained from each donor or from an authorized third party.

Chondrocytes were released from cartilage by sequential enzymatic digestion as previously described [25]. Cells were seeded at $3.5 \times 10^{5}$ cells per well in 12 -well culture plates (Costar, Corning, NY, USA) or at 6 to $7 \times$ $10^{5}$ cells per well in six-well culture plates in DMEM supplemented with $10 \% \mathrm{FCS}$ and were cultivated at $37^{\circ} \mathrm{C}$ for 48 hours. Cells were washed and incubated for an additional 24 hours in DMEM containing $0.5 \%$ FCS before stimulation with IL-1.

\section{Western blot analysis}

Chondrocytes were lysed in ice-cold lysis buffer $(50 \mathrm{mM}$ Tris- $\mathrm{HCl}, \mathrm{pH}$ 7.4, $150 \mathrm{mM} \mathrm{NaCl}, 2 \mathrm{mM}$ ethylenediaminetetraacetic acid (EDTA), $1 \mathrm{mM}$ PMSF, $10 \mu \mathrm{g} / \mathrm{mL}$ each of aprotinin, leupeptin, and pepstatin, 1\% NP-40, $1 \mathrm{mM}$ $\mathrm{Na}_{3} \mathrm{VO}_{4}$, and $1 \mathrm{mM} \mathrm{NaF}$ ). Lysates were sonicated on ice and centrifuged at 12,000 revolutions per minute for 15 minutes. The protein concentration of the supernatant was determined by using the bicinchoninic acid method (Pierce). Twenty micrograms of total cell lysate was subjected to SDS-polyacrylamide gel electrophoresis and electrotransferred to a nitrocellulose membrane (Bio-Rad, Mississauga, ON, Canada). After blocking in $20 \mathrm{mM}$ Tris$\mathrm{HCl}$ pH 7.5 containing $150 \mathrm{mM} \mathrm{NaCl}, 0.1 \%$ Tween 20, and $5 \%$ (wt/vol) non-fat dry milk, blots were incubated overnight at $4^{\circ} \mathrm{C}$ with the primary antibody and washed with a Tris buffer (Tris-buffered saline (TBS) pH 7.5 with $0.1 \%$ Tween 20). The blots were then incubated with HRP-conjugated secondary antibody (Pierce), washed again, incubated with SuperSignal Ultra Chemiluminescent reagent (Pierce), and exposed to Kodak X-Omat film (Eastman Kodak Company, Rochester, NY, USA).

\section{RNA extraction and reverse transcriptase-polymerase chain reaction}

Total RNA from cultured chondrocytes or cartilage was isolated by using the TRIzol reagent (Invitrogen) in accordance with the instructions of the manufacturer. To remove contaminating DNA, isolated RNA was treated with RNase-free DNase I (Ambion, Austin, TX, USA). The RNA was quantitated by using a RiboGreen RNA quantitation kit (Molecular Probes Inc., now part of Invitrogen Corporation, Carlsbad, CA, USA), dissolved in diethylpyrocarbonate-treated $\mathrm{H}_{2} \mathrm{O}$, and stored at $-80^{\circ} \mathrm{C}$ until use. One microgram of total RNA was reverse-transcribed by using Moloney murine leukemia virus reverse transcriptase (Fermentas, Burlington, ON, Canada) as detailed in the guidelines of the manufacturer. One fiftieth of the reverse transcriptase reaction was analyzed by realtime polymerase chain reaction (PCR) as described below. The following primers were used: PPAR $\gamma$, sense, 5'-AAAGAAGCCAACACTAAACC-3' and antisense, 5'-CTTC CATTACGGAGAGATCC-3'; Egr-1, sense, 5'-CTGAC CGCAGAGTCTTTTCCTG-3' and antisense, 5'-TGGGT GCCGCTGAGTAAATG-3'; Sp1, sense 5'-AAACATATCAAAGACCCACCAGAAT-3' and antisense 5'-ATATT GGTGGTAATAAGGGCTGAA-3'; and glyceraldehyde-3phosphate dehydrogenase (GAPDH), sense 5'-CAGAAC ATCATCCCTGCCTCT-3' and antisense 5'-GCTTGACAAAGTGGTCGTTGAG -3’

\section{Real-time polymerase chain reaction}

Real-time PCR analysis was performed in a total volume of $50 \mu \mathrm{L}$ containing template DNA, $200 \mathrm{nM}$ of sense and antisense primers, $25 \mu \mathrm{L}$ of SYBR ${ }^{\circledR}$ Green master mix (Qiagen, Mississauga, ON, Canada) and uracil-N-glycosylase (UNG) (0.5 Units; Epicentre Technologies, Madison, WI, USA). After incubation at $50^{\circ} \mathrm{C}$ for 2 minutes (UNG reaction) and at $95^{\circ} \mathrm{C}$ for 10 minutes (UNG inactivation and activation of the AmpliTaq Gold enzyme), the mixtures were subjected to 40 amplification cycles ( 15 seconds at $95^{\circ} \mathrm{C}$ for denaturation and 1 minute for annealing and extension at $60^{\circ} \mathrm{C}$ ). Incorporation of SYBR ${ }^{\circledR}$ Green dye into PCR products was monitored in real time by using a GeneAmp 5700 Sequence Detection System (Applied Biosystems, Foster City, CA, USA) and allowing determination of the threshold cycle $\left(C_{T}\right)$ at which exponential amplification of PCR products begins. After PCR, dissociation curves were generated with one peak, indicating the specificity of the amplification. $A \mathrm{C}_{\mathrm{T}}$ value was obtained from each amplification curve by using the software provided by the manufacturer (Applied Biosystems).

Relative mRNA expression in chondrocytes was determined by using the $\Delta \Delta C_{\mathrm{T}}$ method, as detailed in the guidelines of the manufacturer (Applied Biosystems). A $\Delta \mathrm{C}_{\mathrm{T}}$ value was first calculated by subtracting the $\mathrm{C}_{\mathrm{T}}$ value for the housekeeping gene $G A P D H$ from the $\mathrm{C}_{\mathrm{T}}$ value for the gene of interest. $\mathrm{A} \Delta \Delta \mathrm{C}_{\mathrm{T}}$ value was then calculated by subtracting the $\Delta \mathrm{C}_{\mathrm{T}}$ value of the control (unstimulated cells) from the $\Delta C_{T}$ value of each treatment. Fold changes compared with the control were then determined by raising 2 to the $-\Delta \Delta C_{\mathrm{T}}$ power. Each PCR generated only the expected specific amplicon as shown by the meltingtemperature profiles of the final product and by gel 
electrophoresis of test PCRs. Each PCR was performed in triplicate on two separate occasions for each independent experiment.

\section{Chromatin immunoprecipitation assay}

The chromatin immunoprecipitation (ChIP) experiments were performed according to the ChIP protocol provided by Upstate/Millipore Biotechnology Inc. (Lake Placid, NY, USA) and previously published protocols [27]. After treatment, the cells were cross-linked with $1 \%$ formaldehyde for 10 minutes at room temperature. The fixed cells were washed twice with ice-cold phosphate-buffered saline containing protease inhibitors and then lysed for 10 minutes at $1 \times 10^{6}$ cells per $200 \mu \mathrm{L}$ of SDS lysis buffer (50 mM Tris- $\mathrm{Cl}$ (pH 8.0), 0.5\% SDS, $100 \mathrm{mM} \mathrm{NaCl}$, and $5 \mathrm{mM}$ EDTA) plus protease inhibitors. The chromatin samples were sonicated to reduce DNA length to 200 to 500 base pairs (bp). Twenty microliters of the supernatant was saved as the input DNA, and the remainder was diluted 1:10 in ChIP dilution buffer (0.01\% SDS, 1.1\% Triton X-100, 1.2 mM EDTA, and $16.7 \mathrm{mM}$ Tris-Cl) containing protease inhibitors. The chromatin samples were precleared with a salmon sperm DNA/protein Aagarose $50 \%$ gel slurry for 3 hours. The samples were then immunoprecipitated overnight at $4{ }^{\circ} \mathrm{C}$ with antibodies specific for either Sp1 and Egr-1. As negative controls, cross-linked chromatin was incubated overnight with control Ig or in the absence of antibody. Immune complexes were recovered by addition of salmon sperm DNA/protein A-agarose slurry for 2 hours at $4{ }^{\circ} \mathrm{C}$. The immune complexes were sequentially washed three times each (5 minutes on a rotating platform), with low salt, high salt, lithium chloride, and Tris/EDTA buffers, and eluted twice with $250 \mu \mathrm{L}$ of $1 \%$ SDS and $0.1 \mathrm{M} \mathrm{NaHCO}_{3}$ for 15 minutes. The eluted material and the DNA input samples were heated for 4 hours at $65^{\circ} \mathrm{C}$ to reverse crosslinking. The samples were treated with $40 \mu \mathrm{g} / \mathrm{mL}$ DNasefree proteinase $\mathrm{K}$ for 1 hour at $45^{\circ} \mathrm{C}$, extracted with phenol-chloroform-isoamyl alcohol and chloroform, and ethanol-precipitated in the presence of $20 \mu \mathrm{g}$ of glycogen. Pellets were suspended in 25 to $30 \mu \mathrm{L}$ of $\mathrm{H}_{2} \mathrm{O}$ and subjected to PCR analysis. The primer sequences used were PPAR $\gamma$ sense, 5'-TCGGATCCCTCCTCGGAAATGG-3' and antisense, 5'-GCGCGACTGGGAGGGA-3'.

\section{Transient transfection}

The luciferase reporter construct pGL3-PPAR $\gamma 1$ p3000, containing a 3,000-bp fragment of the human PPAR $\gamma 1$ gene promoter, was kindly provided by Johan Auwerx (Institut de Génétique et de Biologie moléculaire et Cellulaire, Illkirch, France). Egr-1 expression vector (pcDNA3) was donated by Yuqing Chen (Morehouse School of Medicine, Atlanta, GA, USA) [28]. The $\beta$-galactosidase reporter vector under the control of SV40 promoter (pSV40- $\beta$-gal) was from Promega Corporation (Madison, WI, USA). Transient transfection experiments were performed by using the FuGene- 6 transfection reagent in accordance with the recommended protocol of the manufacturer (Roche Applied Science, Indianapolis, IN, USA). Briefly, chondrocytes were seeded 24 hours prior to transfection at a density of $3 \times 10^{5}$ cells per well in 12 -well plates and transiently transfected with $1 \mu \mathrm{g}$ of the PPAR $\gamma$ promoter construct and $0.5 \mu \mathrm{g}$ of the internal control pSV40- $\beta$-gal. Six hours later, the medium was replaced with DMEM containing 1\% FCS. At 1 day after transfection, the cells were left untreated or treated with IL-1 (100 pg/mL) for 20 hours. In the overexpression experiments, the amount of transfected DNA was kept constant by using the corresponding empty vector. At the end of the indicated treatment, the cells were washed twice in ice-cold phosphatebuffered saline (PBS) and extracts were prepared for firefly luciferase reporter assay (Promega Corporation). Luciferase activity was normalized for transfection efficiency by using the corresponding $\beta$-galactosidase activity.

\section{RNA interference}

Specific small interfering RNA (siRNA) for Sp1, Egr-1, or scrambled control was obtained from Dharmacon Inc. (Lafayette, CO, USA). Chondrocytes were seeded in sixwell plates at $6 \times 10^{5}$ cells per well and incubated for 24 hours. Cells were transfected with $100 \mathrm{nM}$ of siRNA by using the HiPerFect Transfection Reagent (Qiagen) in accordance with the recommendations of the manufacturer. The medium was changed 24 hours later, and the cells were incubated for an additional 24 hours before stimulation with $100 \mathrm{pg} / \mathrm{mL}$ IL-1 for 1 or 20 hours.

\section{Immunohistochemistry}

Cartilage specimens were processed for immunohistochemistry as previously described [25]. The specimens were fixed in $4 \%$ paraformaldehyde and embedded in paraffin. Sections $(5 \mu \mathrm{m})$ of paraffin-embedded specimens were deparaffinized in toluene and dehydrated in a graded series of ethanol. The specimens were then preincubated with chondroitinase $\mathrm{ABC}(0.25 \mathrm{U} / \mathrm{mL}$ in PBS $\mathrm{pH}$ 8.0) for 60 minutes at $37^{\circ} \mathrm{C}$ followed by a 30 -minute incubation with Triton X-100 (0.3\%) at room temperature. Slides were then washed in PBS followed by incubation with $2 \%$ hydrogen peroxide/methanol for 15 minutes. They were further incubated for 60 minutes with $2 \%$ normal serum (Vector Laboratories, Burlingame, CA, USA) and overlaid with an anti-Egr-1 antibody (Santa Cruz Biotechnology, Inc.) for 18 hours at $4^{\circ} \mathrm{C}$ in a humidified chamber. Each slide was washed three times in PBS pH 7.4 and stained by using the avidin-biotin complex method (Vectastain ABC kit; Vector Laboratories). The color was developed with 3,3'-diaminobenzidine (Vector Laboratories) containing hydrogen peroxide. The slides were counterstained with 
eosin. The specificity of staining was evaluated by using an antibody that had been preadsorbed $\left(1\right.$ hour at $\left.37^{\circ} \mathrm{C}\right)$ with a 20 -fold molar excess of the protein fragment corresponding to amino acids 500 to 550 of human Set1A (Santa Cruz Biotechnology, Inc.) and by substituting the primary antibody with non-immune rabbit IgG (Chemicon, Temecula, CA, USA), used at the same concentration as the primary antibody. The evaluation of positive-staining chondrocytes was performed by using our previously published method [25]. For each specimen, six microscopic fields were examined under $40 \times$ magnification. The total number of chondrocytes and the number of chondrocytes staining positive were evaluated, and results were expressed as the percentage of chondrocytes staining positive (cell score).

\section{Statistical analysis}

Data are expressed as the mean \pm SD. Statistical significance was assessed by the two-tailed Student $t$ test. $P$ values of less than 0.05 were considered significant.

\section{Results}

\section{Downregulation of PPAR $\gamma$ expression by IL-1 requires de}

\section{novo protein synthesis}

First, we investigated whether IL-1-mediated downregulation of PPAR $\gamma$ expression in chondrocytes requires de novo protein synthesis. Chondrocytes were incubated with cycloheximide $(10 \mu \mathrm{g} / \mathrm{mL})$ for 30 minutes prior to stimulation with $100 \mathrm{pg} / \mathrm{mL}$ IL-1 for 18 hours, and the levels of PPAR $\gamma$ mRNA were analyzed by real-time PCR. Changes in PPAR $\gamma$ mRNA gene expression were evaluated as percentage over control (untreated cells) after normalization to the internal control gene, GAPDH. As shown in Figure 1, stimulation with IL-1 down-regulated PPAR $\gamma$ mRNA expression to approximately $80 \%$ of control (bar 2 versus bar 1), confirming our earlier findings [25]. Treatment with CHX prevented IL-1-mediated suppression of PPAR $\gamma$ mRNA expression (bar 4 versus bar 2), suggesting that the suppressive effect of IL-1 on PPAR $\gamma$ was an indirect effect and was dependent on de novo protein synthesis.

\section{Downregulation of PPAR $\gamma$ expression by IL-1 correlated with increased Egr-1 expression}

Analysis of the PPAR $\gamma$ promoter identified a putative Egr1-binding site, which overlaps with a Sp1-binding site, between nucleotide- 184 and -173 relative to the transcription start site. To evaluate the role of these transcription factors in the suppressive effect of IL-1 on PPAR $\gamma$ expression, we first examined the effect of IL-1 on their expression in chondrocytes. Cells were treated with IL-1 for different time periods, and the levels of Egr-1 mRNA were quantified by using real-time reverse transcriptase-PCR (RT-PCR). IL-1-induced changes in gene expression were

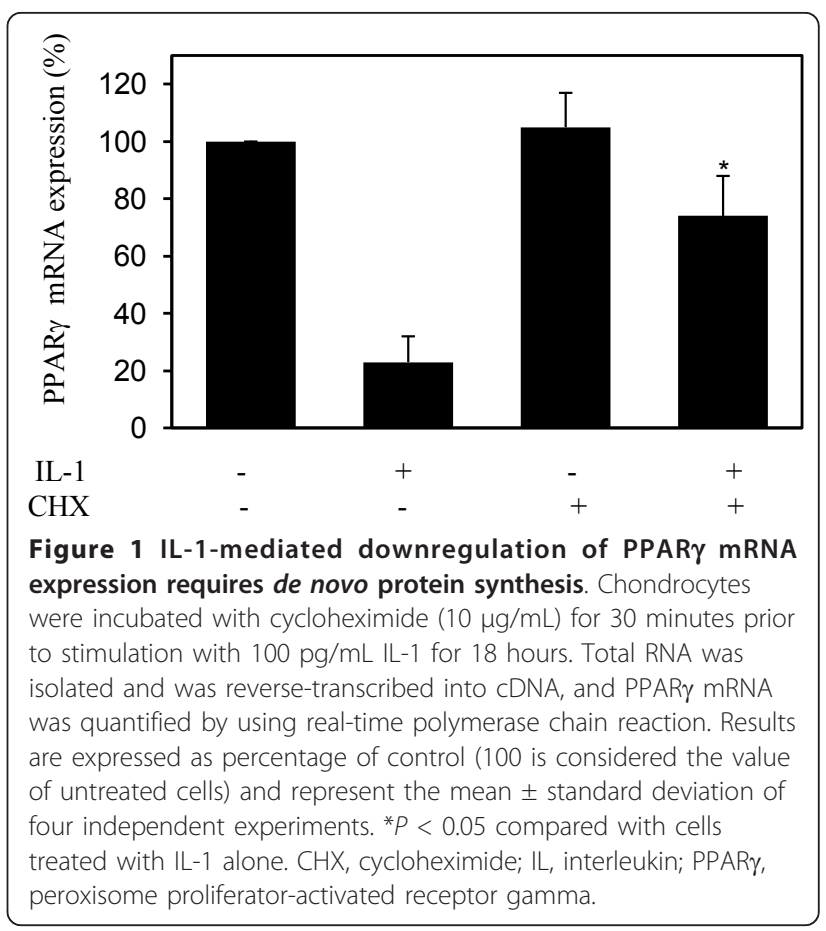

evaluated as fold over control (untreated cells) after normalization to the internal control gene, GAPDH. As shown in Figure 2a, treatment with IL-1 enhanced Egr-1 mRNA expression in a time-dependent manner. Egr-1 mRNA was rapidly and significantly induced at 0.5 hours post-stimulation with IL-1, reached the maximum at 1 hour, and started to decrease at 2 hours. Next, we performed Western blot analysis to determine whether changes in mRNA levels were paralleled by changes in Egr-1 protein levels. Consistent with its effects on Egr-1 mRNA, IL-1 induced Egr-1 protein expression in a time-dependent manner (Figure $2 \mathrm{~d}$ ). Egr-1 protein levels were significantly increased by 0.5 hours post-stimulation, further increased up to 1 hour, then gradually declined starting at 2 hours, and reached basal levels at 8 hours. The induction of Egr- 1 mRNA by IL-1 was also dose-dependent (data not shown). These results indicated that IL-1 is a potent inducer of Egr-1 mRNA and protein expression in human chondrocytes. In contrast, IL-1 had no significant effect on the expression levels of Sp1 mRNA and protein (Figure 2b,e). Importantly, the induction of Egr-1 protein expression by IL-1 preceded the suppression of PPAR $\gamma$ expression (Figure $2 \mathrm{c}, \mathrm{f}$ ). The correlation between the downregulation of PPAR $\gamma$ expression and the induction of Egr-1 suggests a link between these two events.

\section{IL-1 induced the recruitment of Egr-1 and decreased Sp1} occupancy at the PPAR $\gamma$ promoter

To determine whether Egr-1 and Sp1 proteins physically interact with the PPAR $\gamma$ promoter in vivo, we performed 
A

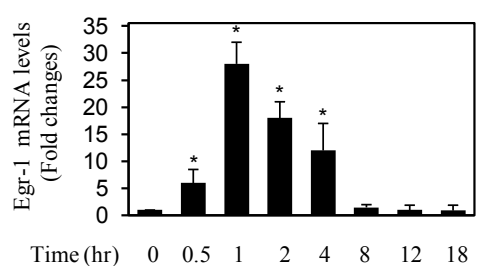

D

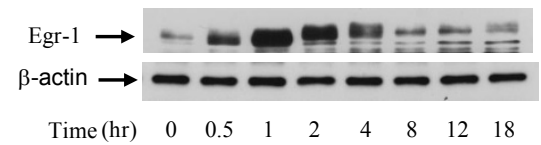

B

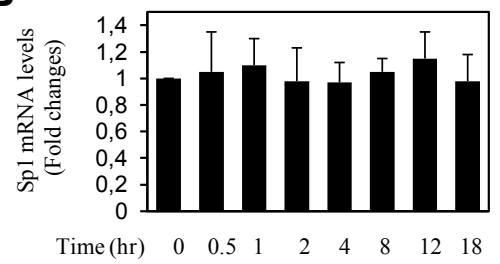

C

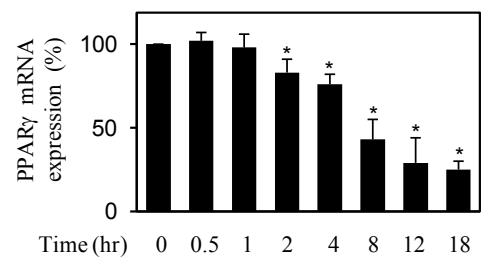

Figure 2 Effect of IL-1 on Egr-1 and Sp1 expression in osteoarthritis chondrocytes. Chondrocytes were treated with 100 pg/mL IL-1 for the indicated time periods. Total RNA was isolated and was reverse-transcribed into cDNA, and Egr-1 (a), Sp1 (b), and PPAR $\gamma$ (c) mRNAs were quantified by using real-time polymerase chain reaction. All experiments were performed in triplicate, and negative controls without template RNA were included in each experiment. $(a, b)$ Results are expressed as fold change, and 1 is considered the value of control (that is, untreated cells). (c) Results are expressed as percentage of control (that is, cells treated with IL-1 alone) and are the mean \pm SD from four independent experiments. The results represent the mean \pm SD of four independent experiments. ${ }^{*} P<0.05$ compared with unstimulated cells. Cell lysates were prepared and analyzed for Egr-1 (d), Sp1 (e), and PPAR $\gamma$ (f) protein expression by Western blotting. In the lower panels, the blots were stripped and reprobed with a specific anti- $\beta$-actin antibody. The blots are representative of similar results obtained from four independent experiments. Egr-1, early growth response gene 1; IL, interleukin; PPAR $\gamma$, peroxisome proliferator-activated receptor gamma; SD, standard deviation; Sp1, specificity protein 1.

ChIP assays. Chondrocytes were stimulated with IL-1 for various time periods, and formaldehyde-cross-linked DNA-proteins were immunoprecipitated by using antibodies specific to Egr-1 and Sp1. Control Ig and no antibody were used as controls. DNA isolated from the immunoprecipitates was analyzed by real-time PCR by using primers amplifying the PPAR $\gamma$ promoter region (bp -322 to -139) that harbors the overlapping Sp1/Egr-1 site.

As shown in Figure 3b, treatment with IL-1 enhanced the levels of Egr-1 at the PPAR $\gamma$ promoter in a timedependent manner. It started to increase significantly at 1 hour after IL- 1 stimulation, reached a maximum at 2 hours, and returned to a near basal level by 8 hours. In contrast, the levels of Sp1 at the PPAR $\gamma$ promoter decreased after IL-1 stimulation (Figure 3c). Sp1 levels were significantly decreased by 2 hours after stimulation, with a further decrease at 4 hours, and remained downregulated until the 18-hour time point. No immunoprecipitable PPAR $\gamma$ promoter DNA was detected with the control Ig and no antibody controls (data not shown).

The recruitment of Egr-1 and reduced occupancy of Sp1 at the PPAR $\gamma$ promoter preceded the suppression of PPAR $\gamma$ transcription by IL-1, suggesting that the recruitment of Egr-1 mediates PPAR $\gamma$ downregulation. Taken together, these results strongly suggest that IL-1-mediated downregulation of PPAR $\gamma$ involves the recruitment of Egr-1 and reduced occupancy of $\mathrm{Sp} 1$.
Overexpression of Egr-1 suppressed, whereas that of Sp1 enhanced, PPAR $\gamma$ promoter activity

To further characterize the functional roles of Sp1 and Egr-1 in IL-1-mediated downregulation of PPAR $\gamma$ expression, we performed transient transfection experiments in which we examined the effects of Egr-1 and Sp1 on PPAR $\gamma$ promoter activity. Chondrocytes were transiently co-transfected with the PPAR $\gamma$ promoter and increasing concentrations of expression vectors that encode Sp1 or Egr-1, and at 18 hours post-transfection, the cells were left untreated or stimulated with IL-1 for an additional 18 hours.

As shown in Figure 4a, treatment with IL-1 suppressed PPAR $\gamma$ promoter activity (bar 5 versus bar 1 ), consistent with previous data [25]. Overexpression of Egr-1 had no significant effect on the basal PPAR $\gamma$ promoter activity (bars 2 to 4 ) but dose-dependently potentiated the suppressive effect of IL-1 (bars 6 to 8). These data suggest that Egr-1 mediates the suppressive effect of IL-1 on PPAR $\gamma$ expression. In contrast, overexpression of Sp1 slightly enhanced (bars 2 to 4 ) the basal activity of the PPAR $\gamma$ promoter and prevented (bars 6 to 8) the suppressive effect of IL- 1 on the PPAR $\gamma$ promoter activity (Figure 4b). These data corroborate the ChIP data, suggesting that Egr-1 mediates the suppressive effect of IL-1 on PPAR $\gamma$ expression, likely by competing with endogenous Sp1. 

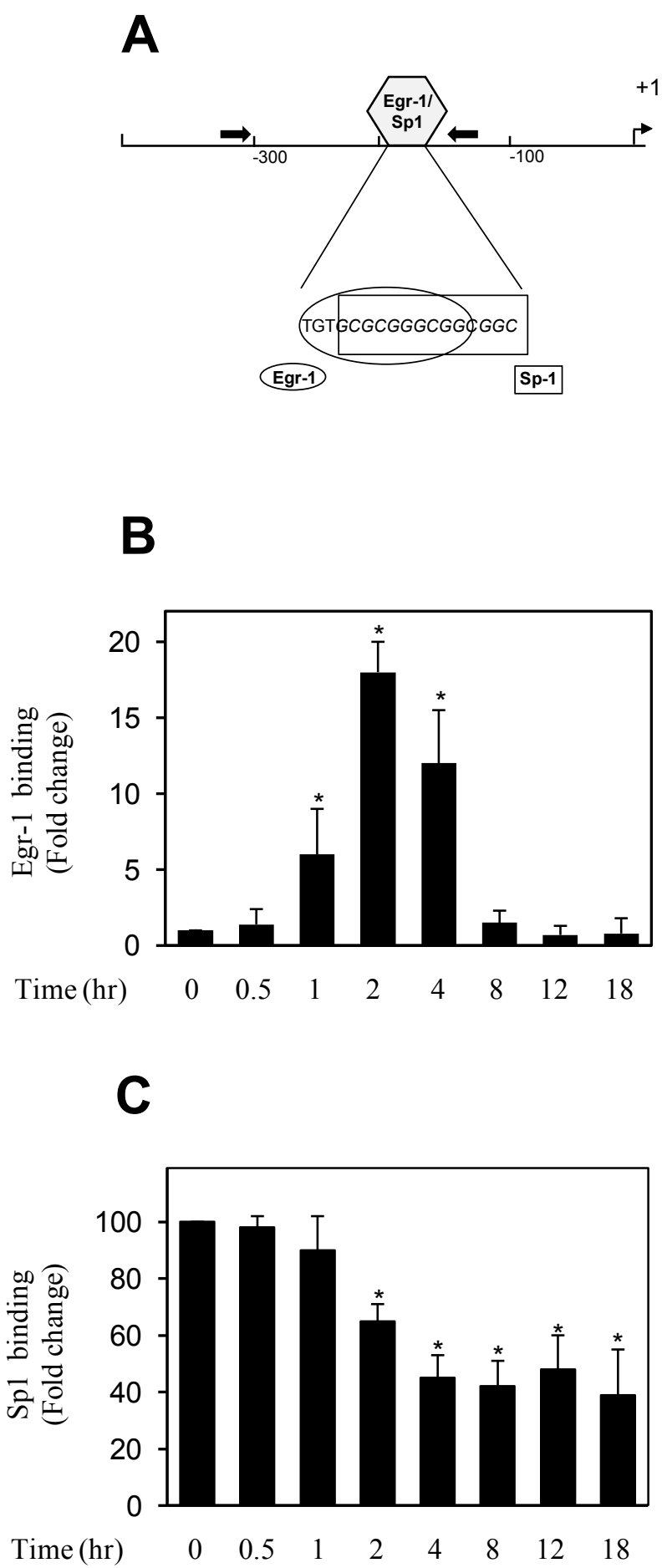

Figure 3 Effect of IL-1 on the recruitment of Egr-1 and Sp1 at the PPAR $\gamma$ promoter. (a) Schematic diagram of the PPAR $\gamma$ promoter showing the locations of the overlapping binding site for Egr-1 and Sp1. Arrows indicate primers used for ChIP analysis. (b,c) Confluent chondrocytes were treated with $100 \mathrm{pg} / \mathrm{mL} \mathrm{IL-1}$ for the indicated time periods, and ChIP assays were performed by using specific anti-Egr-11 (a) and anti-Sp1 (b) antibodies. (a) The results are expressed as fold change of Egr-1 binding to the PPARy promoter relative to untreated cells and represent the mean \pm SD of four independent experiments. (b) Results are expressed as percentage of control (that is, untreated cells) and are the mean \pm SD of four independent experiments. ${ }^{*} P<0.05$ compared with unstimulated cells. ChIP, chromatin immunoprecipitation; Egr-1, early growth response gene 1; IL, interleukin; PPAR $\gamma$, peroxisome proliferator-activated receptor gamma; SD, standard deviation; Sp1, specificity protein 1. 


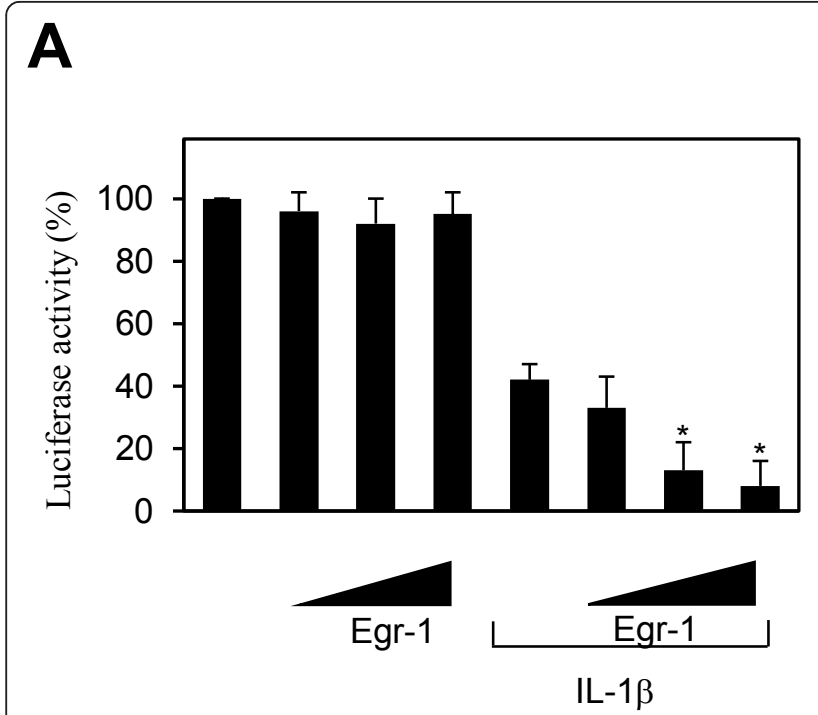

B

Figure 4 Effect of Sp1 and Egr-1 on PPAR $\gamma$ promoter activity. Chondrocytes were co-transfected with the human PPAR $\gamma$ promoter (1 $\mu \mathrm{g} /$ well) and the internal control pSV40- $\beta$-gal $(0.5 \mu \mathrm{g} /$ well) together with increasing concentrations of an expression vector for Egr-1 (a) or Sp1 (b). The total amount of transfected DNA was kept constant by addition of the empty vector. The next day, transfected cells were treated with IL-1 $(100 \mathrm{pg} / \mathrm{mL})$ for 18 hours. Luciferase activity values were determined and normalized to $\beta$-galactosidase activity. Results are expressed as percentage of control (100 is considered the value of untreated cells) and represent the mean \pm SD of four independent experiments. ${ }^{*} P<0.05$ compared with cells treated with IL-1 alone (control). Egr-1, early growth response gene 1; IL, interleukin; PPAR $\gamma$, peroxisome proliferatoractivated receptor gamma; SD, standard deviation; Sp1, specificity protein 1.

Egr-1 silencing with siRNA mitigated IL-1-mediated suppression of PPAR $\gamma$ expression

To further confirm the role of Egr-1, we examined the impact of its silencing by siRNA on IL-1-mediated downregulation of PPAR $\gamma$ protein expression. Chondrocytes were transfected with the scrambled control siRNA, siRNA for Sp1, or siRNA for Egr-1, and after 48 hours of transfection, the cells were stimulated or not with IL-1 for 1 or 18 hours. As shown in Figure 5, transfection with Egr-1 siRNA reversed the suppressive effect of IL-1 on PPAR $\gamma$. In contrast, transfection with Sp1 siRNA or with scrambled control siRNA had no effect. Sp1 protein levels were reduced by as much as $70 \%$ to $75 \%$, and Egr-1 protein levels were almost completely suppressed, confirming silencing of both genes (Figure 5). Together, these data clearly show that Egr-1 is required for IL-1-mediated downregulation of PPAR $\gamma$ protein expression.

\section{Egr-1 levels are elevated in osteoarthritis cartilage}

To determine whether Egr-1 levels were altered under OA conditions, we analyzed the levels of Egr-1 mRNA in total cartilage from normal $(n=9)$ and OA $(n=9)$ donors by using real-time quantitative RT-PCR. As shown in Figure 6a, the level of Egr-1 mRNA was approximately 3.5-fold higher in OA cartilage compared with normal cartilage. Next, we used immunohistochemistry to analyze the localization and the expression level of Egr-1 protein in normal and OA cartilage. As shown in Figure 6c and 6d, Egr-1 was expressed primarily in chondrocytes of the superficial and upper intermediate zones of the cartilage. Statistical evaluation for the cell score revealed that the percentage of cells expressing Egr-1 was approximately 3-fold higher in OA cartilage $(n=9)$ compared with normal cartilage $(n=$ $9)$. The specificity of the staining was confirmed by using an antibody that had been preadsorbed (1 hour at $37^{\circ} \mathrm{C}$ ) with a 20 -fold molar excess of the peptide antigen or non-immune control IgG (data not shown). Together, these data indicate that the expression level of Egr-1 is increased in OA cartilage.

\section{Discussion}

The transcription factor PPAR $\gamma$ has been shown to modulate a number of inflammatory and catabolic responses in articular joint tissues and was suggested to be protective in OA and other arthritic diseases [14-32]. Although many stimuli have been reported to regulate the expression of PPAR $\gamma$ in several cell types (including chondrocytes) [8], little is known about the details of the exact mechanisms that govern its expression.

In the present study, we investigated the roles of the transcription factors Egr-1 and Sp1 in the downregulation of PPAR $\gamma$ expression by IL-1. We demonstrated that IL-1-mediated downregulation of PPAR $\gamma$ coincided with the induction of Egr-1 expression. In addition, 


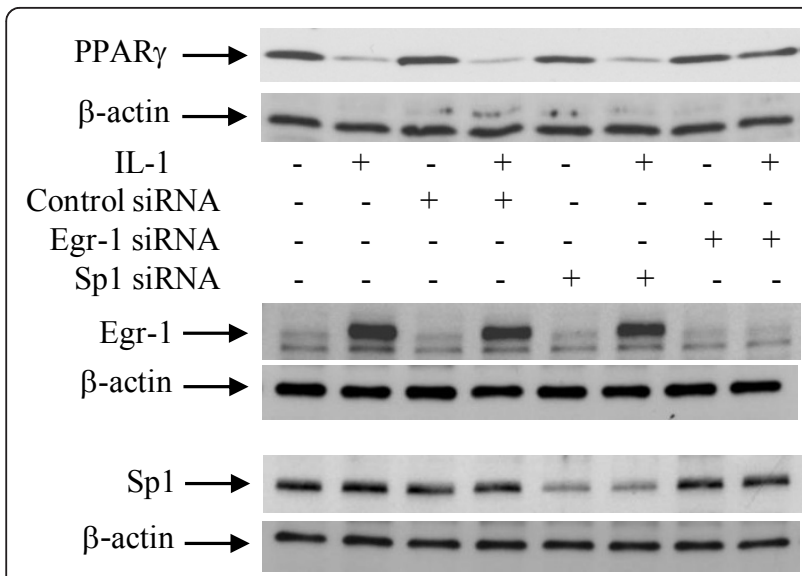

Figure 5 Egr-1 is required for IL-1-mediated suppression of PPAR $\gamma$ expression. Chondrocytes were transfected with $100 \mathrm{nM}$ of control scrambled siRNA, Sp1 siRNA, or Egr-1 siRNA. At 24 hours after transfection, cells were washed, reincubated for another 24 hours, and left untreated or treated with $100 \mathrm{pg} / \mathrm{mL}$ IL-1 for 1 or 18 hours. Cell lysates were prepared and analyzed for Egr-1, Sp1 (1hour treatment), and PPAR $(18$-hour treatment) protein expression by Western blotting. In the lower panels, the blots were stripped and reprobed with a specific anti- $\beta$-actin antibody. The blots are representative of similar results obtained from four independent experiments. Egr-1, early growth response gene 1; IL, interleukin; PPAR $\gamma$, peroxisome proliferator-activated receptor gamma; siRNA, small interfering RNA; Sp1, specificity protein 1.

downregulation of PPAR $\gamma$ expression was preceded by Egr-1 recruitment to, and concomitant reduced Sp1 occupancy at, the PPAR $\gamma$ promoter. Overexpression of Egr-1 suppressed, whereas that of Sp1 enhanced, PPAR $\gamma$ promoter activity. Furthermore, Egr-1 silencing prevented the downregulation of PPAR $\gamma$ expression by IL-1. Together, these data indicate that Egr-1 mediates the suppressive effect of IL-1 on PPAR $\gamma$ expression, likely through displacement of Sp1.

The PPAR $\gamma$ promoter contains an overlapping Sp1/Egr1-binding site. The transcription factor Sp1 is ubiquitously expressed in cell lines and tissues and generally functions as an activator of transcription [29]. The transcription factor Egr-1 is not expressed in normal tissues but is rapidly induced by inflammatory cytokines and growth factors [30-33]. In promoters containing overlapping Sp1/Egr-1-binding sites, Egr-1 can function as a transcriptional activator or repressor. For example, Egr-1 has been shown to compete with Sp1 for an overlapping region in the promoter of platelet-derived growth factorA (PDGF-A) and activates transcription in vascular endothelial cells [34]. Egr-1-mediated transcriptional activation through displacement of Sp1 was also observed for N-myc downregulated gene (NDRG1) [35] and tissue factor [36]. In contrast, other studies reported that Egr-1 competes with $\mathrm{Sp} 1$ and represses the transcription of a number of genes, including the $\beta$-adrenergic receptor
[37], protein tyrosine phosphatase $1 \mathrm{~B}$ [38], sterol regulatory element-binding protein 1 (SREBP-1) [39], the adenosine 5'-triphosphate-binding cassette transporter 2 (ABCA2) [40], and type II collagen [31].

Here, we found that treatment of chondrocytes with IL1 led to a time-dependent increase in Egr-1 expression, whereas the expression of Sp1 was not altered. This is consistent with previous studies showing that IL-1 is a potent inducer of Egr-1 expression in the chondrocyte cell line C-28/I2 [31]. We then examined the effect of IL-1 on the recruitment of Egr-1 and Sp1 to the PPAR $\gamma$ promoter. ChIP results demonstrated that IL-1 induced Egr-1 recruitment to the PPAR $\gamma$ promoter with a parallel reduction in Sp1 occupancy, indicating that Egr-1 displaced the binding of Sp1. It is noteworthy that these changes at the PPAR $\gamma$ promoter were concomitant with the decrease in PPAR $\gamma$ expression, suggesting that Egr-1 recruitment to the PPAR $\gamma$ promoter could mediate the suppressive effect of IL-1 on PPAR $\gamma$ expression.

Using reporter gene assays, we found that IL-1 downregulated PPAR $\gamma$ promoter activity and this effect was further potentiated by co-transfection with an expression vector for Egr-1. In contrast, Sp1 overexpression mitigated the suppressive effect of IL-1. This confirms the respective negative and positive regulation of the PPAR $\gamma$ promoter by Egr-1 and Sp1.

It should be noted that, in the absence of IL-1, transfection with Egr-1 had no effect on PPAR $\gamma$ promoter activity, indicating that Egr-1 needs to be activated to achieve inhibition of PPAR $\gamma$ promoter activity. In this context, it has been reported that the effects of Egr-1 on transcription are modulated through its phosphorylation by casein kinase II [41] and extracellular signal-regulated kinase (Erk) [42]. Egr-1 activity can also be regulated through acetylation, methylation, and ubiquitination, which are known for their impact on the activity of a number of proteins, including transcription factors. Indeed, Egr-1 harbors several consensus sites for acetylation and methylation. Further studies are needed to determine whether the repressive effect of Egr-1 on PPAR $\gamma$ expression involves such post-translational modifications.

Collectively, these results strongly suggest that the induction of Egr-1 expression and its recruitment to the PPAR $\gamma$ promoter mediate the suppressive effect of IL-1 on PPAR $\gamma$ expression. This is further supported by the fact that siRNA-mediated silencing of Egr-1 blocked IL-1induced downregulation of PPAR $\gamma$ protein expression.

There are a number of potential mechanisms through which Egr-1 could mediate the downregulation of PPAR $\gamma$ expression by IL-1. The first possibility is that Egr- 1 can repress transcription by displacing prebound Sp1. This is corroborated by our finding that the recruitment of Egr-1 to the PPAR $\gamma$ promoter paralleled reduced Sp1 occupancy. Moreover, several studies have shown that, 


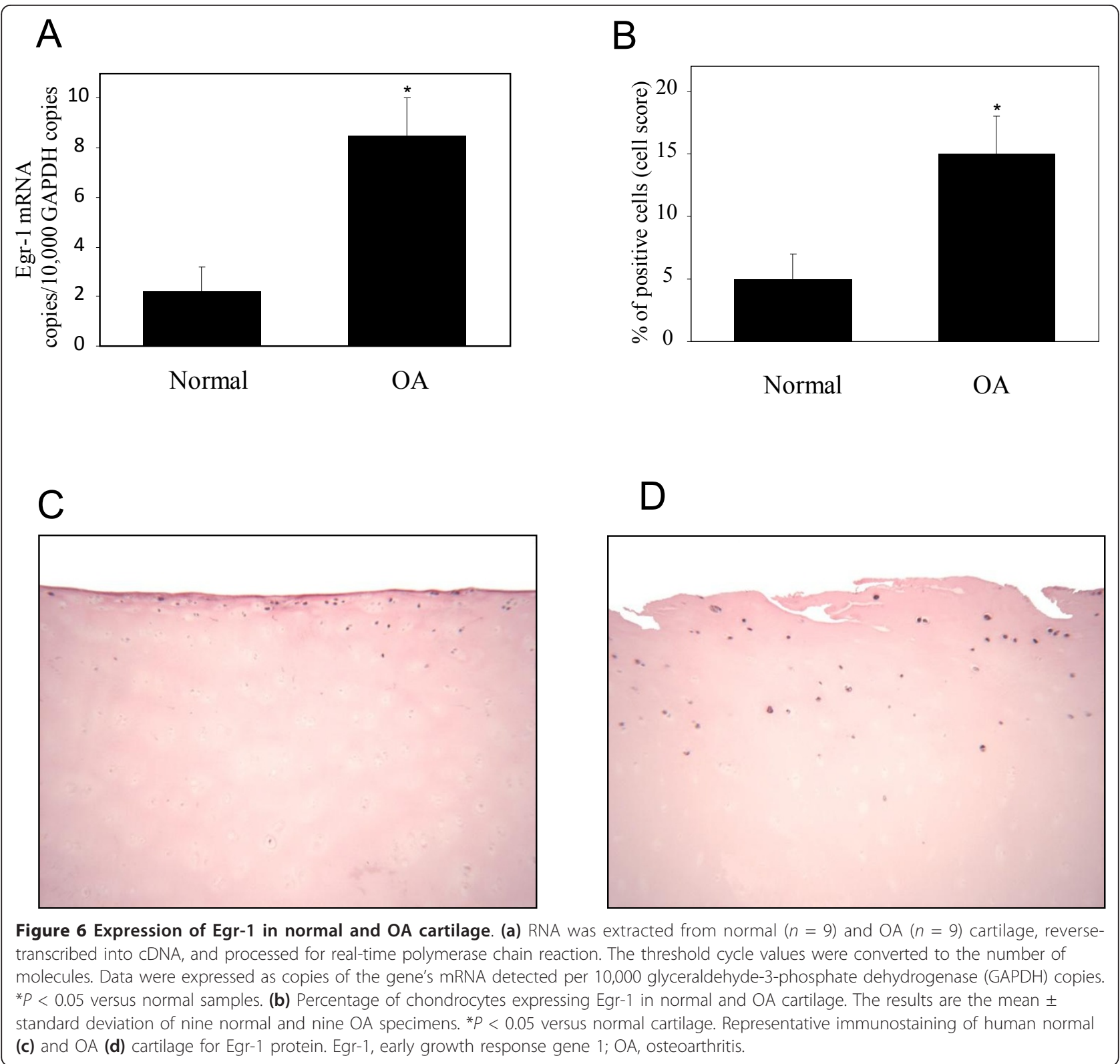

through competition with promoter-associated Sp1, Egr1 represses transcription of genes that harbor overlapping binding sites for Egr-1/Sp1 [34-36]. Secondly, Egr-1 may inhibit PPAR $\gamma$ expression through direct binding to Sp1 and inhibition of its transcriptional activity. In this context, Egr-1 has been shown to inhibit Sp1 transcriptional activity, independently of DNA binding, through mechanisms that involve protein-protein interactions [41]. Thirdly, Egr-1 can also repress transcription by interfering with the interaction between Sp1 and TATAbinding proteins (TBPs). Indeed, Sp1 has been shown to interact with TBPs [43], and Egr-1 was reported to inhibit the binding of TBPs to target promoters [44]. Finally, Egr-1 can attenuate Sp1 activities by competing for limited amounts of general transcriptional co-activators. Of note, Egr-1 has been reported to repress transcription by disrupting the interaction between $\mathrm{Sp} 1$ and CREBbinding protein $(\mathrm{CBP} / \mathrm{p} 300)$ [31]. It is noteworthy that the overlapping binding site for Sp1 and Egr-1 in the PPAR $\gamma$ promoter can also bind the transcription factor Sp3. Indeed, Sp3 and Sp1 recognize and bind to the same DNA element with similar affinity and their DNA-binding domains share over 90\% DNA sequence homology. Therefore, it is possible that $\mathrm{Sp} 3$ contributes to the regulatory effect of IL-1 on PPAR $\gamma$ expression. Indeed, IL-1 induces Sp3 expression and Sp3 down-regulates the transcriptional activity of $\mathrm{Sp} 1$ in chondrocytes. Such a mechanism was documented in IL-1-induced downregulation of 
type II transforming growth factor-beta (TGF- $\beta$ ) receptor [45]. In addition to containing the overlapping Sp1/Egr-1binding sites, the PPAR $\gamma$ promoter contains binding sites for other transcription factors known to be activated by IL-1, including activation protein-1 (AP-1), nuclear factorkappa-B (NF- $\kappa \mathrm{B})$, nuclear factor of activated T cells (NF$\mathrm{AT})$, and myogenic differentiation 1 (MyoD). Although the role of these elements in IL-1-mediated downregulation of PPAR $\gamma$ expression is still unknown, we cannot exclude the possibility that activation of these transcription factors by IL-1 also participates in the downregulation of PPAR $\gamma$ expression. This is supported by the observation that siRNA-mediated silencing of Egr-1 did not completely reverse the suppressive effect of IL-1 on PPAR $\gamma$ expression.

The involvement of Egr-1 in IL-1-mediated downregulation of PPAR $\gamma$ expression may be of relevance for other stimuli known to modulate PPAR $\gamma$ expression. For instance, TNF- $\alpha$ and oxidative stress are known to down-regulate PPAR $\gamma$ expression [46,47]. Interestingly, TNF- $\alpha$ and oxidative stress are potent inducers of Egr-1 expression $[30,48]$. Therefore, it is possible that the induction of Egr-1 expression is part of the mechanisms by which TNF- $\alpha$ and oxidative stress down-regulate PPAR $\gamma$ expression.

Several studies have suggested roles for Egr-1 in the regulation of several genes involved in the pathogenesis of arthritis. For example, Egr-1 was shown to mediate TNF- $\alpha$-induced MMP-9 [32], IL-1-mediated suppression of type II collagen [31], and TNF- $\alpha$-mediated suppression of aggrecan [33]. Egr-1 was also shown to positively regulate several inflammatory responses. Indeed, Egr-1 mediates IL-1-induced mPGES-1 expression and PGE ${ }_{2}$ production in several cell types, including chondrocytes and synovial fibroblasts [22]. Furthermore, Egr-1 contributes to lipopolysaccharide-induced transcription of suppressor of cytokine signaling-1 (SOCS-1), a key regulator of lipopolysaccharide-induced cytokine production [49]. Egr-1 was also demonstrated to play a critical role in the induction of a number of chemokines [50] and cytokines, including IL-2, TNF- $\alpha$ [51], IL-6, granulocyte colony-stimulating factor, and intracellular adhesion molecule [52]. In addition to inflammatory and catabolic responses, chondrocyte apoptosis plays a significant role in the pathogenesis of OA. Of importance, Egr-1 was shown to positively regulate the expression of several pro-apoptotic factors, including TNF- $\alpha$-related apoptosis-inducing ligand (TRAIL) [53] and phosphatase and tensin homo$\log$ (PTEN) [54]. These data, together with our findings that Egr-1 mediates the suppressive effect of IL-1 on PPAR $\gamma$ expression, suggest that therapeutic interventions that control Egr-1 expression may have protective effects in OA. Further in vivo studies will be required to elucidate the exact role of Egr-1 in cartilage integrity and the pathogenesis of OA.
Finally, we showed that OA cartilage expresses high levels of Egr-1 compared with normal tissue. Positive immunoreactive staining for Egr-1 was located primarily in chondrocytes of the superficial layers. Interestingly, the levels of IL-1, a key player in the pathogenesis of OA, were reported to be elevated in these regions [55], suggesting that IL-1 may be responsible for the observed increase in Egr-1 in OA cartilage. This is consistent with our findings that IL-1 is a potent inducer of Egr-1 expression in cultured chondrocytes. Our results are consistent with the findings of Trabandt and colleagues [56], who showed elevated Egr-1 expression in rheumatoid synovium, which is characterized by increased production of inflammatory cytokines. In contrast, Wang and colleagues [57] reported reduced expression of Egr-1 in OA cartilage. These apparent discrepancies in the expression of Egr-1 may be due to differences in study design. Indeed, Wang and colleagues [57] performed their immunohistochemical study by using cartilage from two donors: one OA and one normal. The discrepancies may also lie in differences in tissue processing, antibody concentrations, or staining detection methodology.

\section{Conclusions}

These data suggest that Egr-1 mediates the suppressive effect of IL-1 on PPAR $\gamma$ expression through a mechanism involving displacement of prebound Sp1. They also suggest that this pathway could be a potential target for pharmacologic intervention in the treatment of OA and possibly other arthritic diseases.

\section{Abbreviations}

Bp: base pairs; ChIP: chromatin immunoprecipitation; CHX: cycloheximide; COX2: cyclooxygenase-2; CT: threshold cycle; DMEM: Dulbecco's modified Eagle's medium; EDTA: ethylenediaminetetraacetic acid; Egr-1: early growth response gene 1, FCS: fetal calf serum; GAPDH: glyceraldehyde-3-phosphate

dehydrogenase; HRP: horseradish peroxidase; IgG: immunoglobulin G; IL: interleukin; iNOS: inducible nitric-oxide synthase; MMP: matrix

metalloproteinase; mPGES-1: microsomal prostaglandin E synthase 1; NO: nitric oxide; OA: osteoarthritis; PBS: phosphate-buffered saline; PCR: polymerase chain reaction; $\mathrm{PGE}_{2}$ : prostaglandin $\mathrm{E}_{2}$; PMSF: phenylmethylsulphonyl fluoride; PPAR: peroxisome proliferator-activated receptor; RT-PCR: reverse transcriptasepolymerase chain reaction; SD: standard deviation; siRNA: small interfering RNA; Sp1: specificity protein 1; TBP: TATA-binding protein; TNFa: tumor necrosis factor-alpha; UNG: uracil-N-glycosylase.

\section{Acknowledgements}

This work was supported by Canadian Institutes of Health Research (CIHR) grant MOP-84282 and the Fonds de la Recherche du Centre de Recherche du Centre Hospitalier de I'Université de Montréal (CHUM). The authors thank Virginie Wallis for her editorial assistance.

\section{Author details}

${ }^{1}$ Osteoarthritis Research Unit, Research Centre of the University of Montreal Hospital Center (CR-CHUM), Notre-Dame Hospital, 1560 Sherbrooke Street East, J.A. DeSève Pavillion, Y-2628, and Department of Medicine, University of Montreal, Montreal, QC H2L 4M1, Canada. ${ }^{2}$ Research Centre, Sacré-Coeur Hospital, 5400 Gouin Boulevard West, Montreal, QC H4J 1C5, Canada. ${ }^{3}$ Centre de Convalescence, de Charmilles Pavillion, 1487 des Laurentides Boulevard, Montreal, QC H7M 2Y3, Canada. 


\section{Authors' contributions}

S-SN designed and carried out cell and real-time RT-PCR experiments and some immunoblotting experiments. FEE contributed to the study design and carried out immunoblotting experiments. HA performed siRNA and some immunohistochemistry experiments. MK and MB performed transient transfection experiments and participated in data analysis. JM-P, J-PP, and ND helped to obtain tissues and participated in the study design and in some immunohistochemistry experiments. HF conceived, designed, and coordinated the study, carried out some cell experiments, and drafted the manuscript. All authors contributed to the analysis and interpretation of data and read and approved the final manuscript.

\section{Competing interests}

The authors declare that they have no competing interests.

Received: 15 November 2011 Revised: 17 February 2012

Accepted: 28 March 2012 Published: 28 March 2012

\section{References}

1. Kapoor M, Martel-Pelletier J, Lajeunesse D, Pelletier JP, Fahmi H: Role of proinflammatory cytokines in the pathophysiology of osteoarthritis. Nat Rev Rheumatol 2011, 7:33-42.

2. Montagner A, Rando G, Degueurce G, Leuenberger N, Michalik L, Wahli W: New insights into the role of PPARs. Prostaglandins Leukot Essent Fatty Acids 2011, 85:235-243.

3. Hiukka A, Maranghi M, Matikainen N, Taskinen MR: PPARalpha: an emerging therapeutic target in diabetic microvascular damage. Nat Rev Endocrinol 2010, 6:454-463.

4. Hall MG, Quignodon L, Desvergne B: Peroxisome proliferator-activated receptor beta/delta in the brain: facts and hypothesis. PPAR Res 2008, 2008:780452.

5. Wang D, DuBois RN: Therapeutic potential of peroxisome proliferatoractivated receptors in chronic inflammation and colorectal cancer. Gastroenterol Clin North Am 2010, 39:697-707.

6. Wang N, Yin R, Liu Y, Mao G, Xi F: Role of peroxisome proliferatoractivated receptor-gamma in atherosclerosis: an update. Circ J 2011, 75:528-535.

7. Youssef J, Badr M: Peroxisome proliferator-activated receptors and cancer: challenges and opportunities. Br J Pharmacol 2011, 164:68-82.

8. Fahmi H, Martel-Pelletier J, Pelletier JP, Kapoor M: Peroxisome proliferatoractivated receptor gamma in osteoarthritis. Mod Rheumatol 2011, 21:1-9.

9. Fahmi H, Di Battista JA, Pelletier JP, Mineau F, Ranger P, Martel-Pelletier J: Peroxisome proliferator-activated receptor gamma activators inhibit interleukin-1 beta-induced nitric oxide and matrix metalloproteinase 13 production in human chondrocytes. Arthritis Rheum 2001, 44:595-607.

10. Fahmi H, Pelletier JP, Mineau F, Martel-Pelletier J: $15 d-P G J(2)$ is acting as a 'dual agent' on the regulation of COX-2 expression in human osteoarthritic chondrocytes. Osteoarthritis Cartilage 2002, 10:845-848.

11. Bordji K, Grillasca JP, Gouze JN, Magdalou J, Schohn H, Keller JM, Bianchi A, Dauca M, Netter P, Terlain B: Evidence for the presence of peroxisome proliferator-activated receptor (PPAR) alpha and gamma and retinoid Z receptor in cartilage. PPARgamma activation modulates the effects of interleukin-1 beta on rat chondrocytes. J Biol Chem 2000, 275:12243-12250.

12. Moulin D, Poleni PE, Kirchmeyer M, Sebillaud $S$, Koufany M, Netter $P$, Terlain B, Bianchi A, Jouzeau JY: Effect of peroxisome proliferator activated receptor (PPAR)gamma agonists on prostaglandins cascade in joint cells. Biorheology 2006, 43:561-575.

13. Li X, Afif H, Cheng S, Martel-Pelletier J, Pelletier JP, Ranger P, Fahmi H: Expression and regulation of microsomal prostaglandin E synthase-1 in human osteoarthritic cartilage and chondrocytes. J Rheumatol 2005, 32:887-895.

14. Bianchi A, Moulin D, Sebillaud S, Koufany M, Galteau MM, Netter P, Terlain B, Jouzeau JY: Contrasting effects of peroxisome-proliferatoractivated receptor (PPAR)gamma agonists on membrane-associated prostaglandin E2 synthase-1 in IL-1beta-stimulated rat chondrocytes: evidence for PPARgamma-independent inhibition by 15-deoxyDelta12,14prostaglandin J2. Arthritis Res Ther 2005, 7:R1325-1337.

15. Francois M, Richette $P$, Tsagris L, Raymondjean M, Fulchignoni-Lataud MC, Forest C, Savouret JF, Corvol MT: Peroxisome proliferator-activated receptor-gamma down-regulates chondrocyte matrix metalloproteinase1 via a novel composite element. J Biol Chem 2004, 279:28411-28418.
16. Chabane N, Zayed N, Benderdour M, Martel-Pelletier J, Pelletier JP, Duval N, Fahmi H: Human articular chondrocytes express 15-lipoxygenase-1 and -2: potential role in osteoarthritis. Arthritis Res Ther 2009, 11:R44.

17. Ji JD, Cheon H, Jun JB, Choi SJ, Kim YR, Lee YH, Kim TH, Chae IJ, Song GG, Yoo DH, Kim SY, Sohn J: Effects of peroxisome proliferator-activated receptor-gamma (PPAR-gamma) on the expression of inflammatory cytokines and apoptosis induction in rheumatoid synovial fibroblasts and monocytes. J Autoimmun 2001, 17:215-221.

18. Simonin MA, Bordii K, Boyault S, Bianchi A, Gouze E, Becuwe P, Dauca M, Netter P, Terlain B: PPAR-gamma ligands modulate effects of LPS in stimulated rat synovial fibroblasts. Am J Physiol Cell Physiol 2002, 282: C125-133.

19. Fahmi H, Pelletier JP, Di Battista JA, Cheung HS, Fernandes J, MartelPelletier J: Peroxisome proliferator-activated receptor gamma acitvators inhibit MMP-1 production in human synovial fibroblasts by reducing the activity of the activator protein 1. Osteoarthritis Cartilage 2002, 10:100-108.

20. Tsubouchi Y, Kawahito Y, Kohno M, Inoue K, Hla T, Sano H: Feedback control of the arachidonate cascade in rheumatoid synoviocytes by 15 deoxy-Delta(12,14)-prostaglandin J2. Biochem Biophys Res Commun 2001, 283:750-755.

21. Farrajota K, Cheng S, Martel-Pelletier J, Afif H, Pelletier JP, Li X, Ranger $P$, Fahmi H: Inhibition of interleukin-1 beta-induced cyclooxygenase 2 expression in human synovial fibroblasts by 15 -deoxy-Delta12,14prostaglandin $\mathrm{J} 2$ through a histone deacetylase-independent mechanism. Arthritis Rheum 2005, 52:94-104.

22. Cheng S, Afif H, Martel-Pelletier J, Pelletier JP, Li X, Farrajota K, Lavigne M, Fahmi H: Activation of peroxisome proliferator-activated receptor gamma inhibits interleukin-1 beta-induced membrane-associated prostaglandin E2 synthase-1 expression in human synovial fibroblasts by interfering with Egr-1.J Biol Chem 2004, 279:22057-22065.

23. Kobayashi T, Notoya K, Naito T, Unno S, Nakamura A, Martel-Pelletier J, Pelletier JP: Pioglitazone, a peroxisome proliferator-activated receptor gamma agonist, reduces the progression of experimental osteoarthritis in guinea pigs. Arthritis Rheum 2005, 52:479-487.

24. Boileau C, Martel-Pelletier J, Fahmi H, Mineau F, Boily M, Pelletier JP: The peroxisome proliferator-activated receptor gamma agonist pioglitazone reduces the development of cartilage lesions in an experimental dog model of osteoarthritis: in vivo protective effects mediated through the inhibition of key signaling and catabolic pathways. Arthritis Rheum 2007, 56:2288-2298.

25. Afif H, Benderdour M, Mfuna-Endam L, Martel-Pelletier J, Pelletier JP, Duval N, Fahmi H: Peroxisome proliferator-activated receptor gamma1 expression is diminished in human osteoarthritic cartilage and is downregulated by interleukin-1 beta in articular chondrocytes. Arthritis Res Ther 2007, 9:R31.

26. Altman RD: Criteria for the classification of osteoarthritis of the knee and hip. Scand J Rheumatol Suppl 1987, 65:31-39.

27. El Mansouri FE, Chabane N, Zayed N, Kapoor M, Benderdour M, MartelPelletier J, Pelletier JP, Duval N, Fahmi H: H3K4 methylation by Set1A contributes to IL-1-induced COX-2 and iNOS expression in human OA chondrocytes. Arthritis Rheum 2010, 63:168-179.

28. Zhu X, Lin Y, Bacanamwo M, Chang L, Chai R, Massud I, Zhang J, GarciaBarrio MT, Thompson WE, Chen YE: Interleukin-1 beta-induced Id 2 gene expression is mediated by Egr-1 in vascular smooth muscle cells. Cardiovasc Res 2007, 76:141-148.

29. Wierstra I: Sp1: emerging roles-beyond constitutive activation of TATAless housekeeping genes. Biochem Biophys Res Commun 2008, 372:1-13.

30. Chaudhary LR, Cheng SL, Avioli LV: Induction of early growth response-1 gene by interleukin-1 beta and tumor necrosis factor-alpha in normal human bone marrow stromal an osteoblastic cells: regulation by a protein kinase C inhibitor. Mol Cell Biochem 1996, 156:69-77.

31. Tan L, Peng H, Osaki M, Choy BK, Auron PE, Sandell LJ, Goldring MB: Egr-1 mediates transcriptional repression of COL2A1 promoter activity by interleukin-1 beta. J Biol Chem 2003, 278:17688-17700.

32. Shin SY, Kim JH, Baker A, Lim Y, Lee YH: Transcription factor Egr-1 is essential for maximal matrix metalloproteinase-9 transcription by tumor necrosis factor alpha. Mol Cancer Res 2010, 8:507-519.

33. Rockel JS, Bernier SM, Leask A: Egr-1 inhibits the expression of extracellular matrix genes in chondrocytes by TNFalpha-induced MEK/ ERK signalling. Arthritis Res Ther 2009, 11:R8. 
34. Khachigian LM, Williams AJ, Collins T: Interplay of Sp1 and Egr-1 in the proximal platelet-derived growth factor A-chain promoter in cultured vascular endothelial cells. J Biol Chem 1995, 270:27679-27686.

35. Zhang P, Tchou-Wong KM, Costa M: Egr-1 mediates hypoxia-inducible transcription of the NDRG1 gene through an overlapping Egr-1/Sp1 binding site in the promoter. Cancer Res 2007, 67:9125-9133.

36. Rong Y, Hu F, Huang R, Mackman N, Horowitz JM, Jensen RL, Durden DL, Van Meir EG, Brat DJ: Early growth response gene-1 regulates hypoxiainduced expression of tissue factor in glioblastoma multiforme through hypoxia-inducible factor-1-independent mechanisms. Cancer Res 2006, 66:7067-7074

37. Bahouth SW, Beauchamp MJ, Vu KN: Reciprocal regulation of beta(1)adrenergic receptor gene transcription by $\mathrm{Sp} 1$ and early growth response gene 1: induction of EGR-1 inhibits the expression of the beta (1)-adrenergic receptor gene. Mol Pharmacol 2002, 61:379-390.

38. Fukada T, Tonks NK: The reciprocal role of Egr-1 and Sp family proteins in regulation of the PTP1B promoter in response to the p210 Bcr-Abl oncoprotein-tyrosine kinase. J Biol Chem 2001, 276:25512-25519.

39. Fernandez-Alvarez A, Tur G, Lopez-Rodas G, Casado M: Reciprocal regulation of the human sterol regulatory element binding protein (SREBP)-1a promoter by Sp1 and EGR-1 transcription factors. FEBS Lett 2008, 582:177-184

40. Davis WJ, Chen ZJ, lle KE, Tew KD: Reciprocal regulation of expression of the human adenosine $5^{\prime}$-triphosphate binding cassette, sub-family $A$, transporter 2 (ABCA2) promoter by the early growth response-1 (EGR-1) and Sp-family transcription factors. Nucleic Acids Res 2003, 31:1097-1107.

41. Srivastava S, Weitzmann MN, Kimble RB, Rizzo M, Zahner M, Milbrandt J, Ross FP, Pacifici R: Estrogen blocks M-CSF gene expression and osteoclast formation by regulating phosphorylation of Egr-1 and its interaction with Sp-1. J Clin Invest 1998, 102:1850-1859.

42. Zhang F, Lin M, Abidi P, Thiel G, Liu J: Specific interaction of Egr1 and c/ EBPbeta leads to the transcriptional activation of the human low density lipoprotein receptor gene. J Biol Chem 2003, 278:44246-44254.

43. Emili A, Greenblatt J, Ingles CJ: Species-specific interaction of the glutamine-rich activation domains of Sp1 with the TATA box-binding protein. Mol Cell Biol 1994, 14:1582-1593.

44. Tatarowicz WA, Martin CE, Pekosz AS, Madden SL, Rauscher F Jr, Chiang SY, Beerman TA, Fraser NW: Repression of the HSV-1 latency-associated transcript (LAT) promoter by the early growth response (EGR) proteins: involvement of a binding site immediately downstream of the TATA box. J Neurovirol 1997, 3:212-224.

45. Bauge C, Beauchef G, Leclercq S, Kim SJ, Pujol JP, Galera P, Boumediene K: NFkappaB mediates IL-1beta-induced down-regulation of TbetaRII through the modulation of Sp3 expression. J Cell Mol Med 2008, 12:1754-1766.

46. Guilherme A, Tesz GJ, Guntur KV, Czech MP: Tumor necrosis factor-alpha induces caspase-mediated cleavage of peroxisome proliferator-activated receptor gamma in adipocytes. J Biol Chem 2009, 284:17082-17091.

47. Yun Z, Maecker HL, Johnson RS, Giaccia AJ: Inhibition of PPAR gamma 2 gene expression by the HIF-1-regulated gene DEC1/Stra13: a mechanism for regulation of adipogenesis by hypoxia. Dev Cell 2002, 2:331-341.

48. Wang CC, Sharma G, Draznin B: Early growth response gene-1 expression in vascular smooth muscle cells effects of insulin and oxidant stress. Am J Hypertens 2006, 19:366-372.

49. Mostecki J, Showalter BM, Rothman PB: Early growth response-1 regulates lipopolysaccharide-induced suppressor of cytokine signaling-1 transcription. J Biol Chem 2005, 280:2596-2605.

50. Cho SJ, Kang MJ, Homer RJ, Kang HR, Zhang X, Lee PJ, Elias JA, Lee CG: Role of early growth response-1 (Egr-1) in interleukin-13-induced inflammation and remodeling. J Biol Chem 2006, 281:8161-8168.

51. Decker EL, Nehmann N, Kampen E, Eibel H, Zipfel PF, Skerka C: Early growth response proteins (EGR) and nuclear factors of activated $T$ cells (NFAT) form heterodimers and regulate proinflammatory cytokine gene expression. Nucleic Acids Res 2003, 31:911-921.

52. Prince JM, Ming MJ, Levy RM, Liu S, Pinsky DJ, Vodovotz Y, Billiar TR: Early growth response 1 mediates the systemic and hepatic inflammatory response initiated by hemorrhagic shock. Shock 2007, 27:157-164.

53. Fu M, Zhu X, Zhang J, Liang J, Lin Y, Zhao L, Ehrengruber MU, Chen YE: Egr-1 target genes in human endothelial cells identified by microarray analysis. Gene 2003, 315:33-41.
54. Virolle T, Adamson ED, Baron V, Birle D, Mercola D, Mustelin T, de Belle I: The Egr-1 transcription factor directly activates PTEN during irradiationinduced signalling. Nat Cell Biol 2001, 3:1124-1128.

55. Melchiorri C, Meliconi R, Frizziero L, Silvestri T, Pulsatelli L, Mazzetti I, Borzi RM, Uguccioni M, Facchini A: Enhanced and coordinated in vivo expression of inflammatory cytokines and nitric oxide synthase by chondrocytes from patients with osteoarthritis. Arthritis Rheum 1998, 41:2165-2174.

56. Trabandt A, Aicher WK, Gay RE, Sukhatme VP, Fassbender HG, Gay S: Spontaneous expression of immediately-early response genes c-fos and egr-1 in collagenase-producing rheumatoid synovial fibroblasts. Rheumatol Int 1992, 12:53-59.

57. Wang FL, Connor JR, Dodds RA, James IE, Kumar S, Zou C, Lark MW, Gowen M, Nuttall ME: Differential expression of egr-1 in osteoarthritic compared to normal adult human articular cartilage. Osteoarthritis Cartilage 2000, 8:161-169.

\section{doi:10.1186/ar3788}

Cite this article as: Nebbaki et al.: Egr-1 contributes to IL-1-mediated down-regulation of peroxisome proliferator-activated receptor $\gamma$ expression in human osteoarthritic chondrocytes. Arthritis Research \& Therapy 2012 14:R69.

\section{Submit your next manuscript to BioMed Central and take full advantage of:}

- Convenient online submission

- Thorough peer review

- No space constraints or color figure charges

- Immediate publication on acceptance

- Inclusion in PubMed, CAS, Scopus and Google Scholar

- Research which is freely available for redistribution

Submit your manuscript at www.biomedcentral.com/submit
Biomed Central 